DOI https://doi.org/10.30525/978-9934-26-111-4-51

\title{
ВПЛИВ ЛУЧНИХ АГРОЕКОСИСТЕМ НА ЗМІНУ ЕНЕРГЕТИЧНОЇ ЄМНОСТІ ГРУНТУ
}

\author{
Панахид Г. Я. \\ доктор сільськогосподарських наук, \\ стариий науковий співробітник, вчений секретар \\ Інститут сільського господарства Карпатського регіону \\ Національної академії аграрних наук України
}

Коник Г. С.

доктор сільськогосподарських наук, старший науковий співробітник, перший заступник директора з наукової роботи Інститут сільського господарства Карпатського регіону Національної академії аграрних наук Украӥни

c. Оброшине, Пустомитівський район, Львівська область, Украйна

Лучні агроекосистеми мають здатність до акумуляції природних факторів: самовідновлення довготривалих фітоценозів, нагромадження симбіотично фіксованого азоту бобовими видами трав, підвищення родючості грунту завдяки накопиченню органічних речовин тощо $[1,2]$. Коренева система лучних травостоїв забезпечує не лише надходження поживних речовин із грунту в надземну частину агрофітоценозів, а й має суттєву післядію на зміну родючості грунту в результаті ії̈ накопичення, часткового відмирання під час використання та мінералізації [3]. Мінералізація відмерлих коренів проходить постійно і активно у всіх лучних грунтах нормального зволоження, що обумовлено достатньою кількістю кисню в грунтовому повітрі $\mathrm{i}$ відсутністю $\mathrm{CO}_{2}$. Крім цього, бобові багаторічні трави є структуроутворювачами грунту. Для прикладу: близько $60 \%$ усієї біомаси конюшини лучної становить коренева система; після оранки поля, де росла конюшина, зменшується ущільнення грунту, покращується його аерація, грунт збагачується органічною речовиною, гумусом, а після їхньої мінералізації - макро- і мікроелементами живлення [4]. Вирощування бобових трав забезпечує скорочення в 2,5-3 рази витрат невідновлюваної енергії за рахунок ризобіальної фіксації азоту. Утримання в травостої бобових компонентів в межах 30-50 \% сприяє не лише підвищенню урожайності сухої речовини і поживності корму, а й мінімізує втрати азоту в навколишнє середовище $[5,6]$. 
Для виявлення антропогенних факторів, які в поєднанні із природними, впливають на накопичення органічної речовини, яка $\epsilon$ джерелом гумусу в грунті, на довготривалому стаціонарному досліді Інституту сільського господарства Карпатського регіону визначено валову енергію яка накопичується в корінні довготривало (37-41річного різнотравно-злакового) та новоствореного (бобово-злакового) травостоїв.

Найбільше накопичення валової енергії в коренях трав 37-41-річного лучного агрофітоценозу (329,6 ГДж/га) зафіксовано за використання його без застосування добрив. Застосування фосфорних та калійних добрив зумовило зниження валової енергії, закріпленої в кореневій масі, на 12,9 ГДж/га. За використання повного мінерального удобрення, внаслідок зниження маси коріння, знизилася i валова енергія в ньому. Так найменше їі закріпилося в корінні травостою, який удобрювали азотними добривами в дозі 90 кг/га діючої речовини із наростанням доз до осені. Збільшення доз азотного удобрення призвело до збільшення валової енергії, закріпленої в кореневій масі, причому за рівномірного внесення азоту незалежно від дози, вміст енергії був вищим.

У кореневій масі новоствореного бобово-злакового лучного агрофітоценозу без застосування удобрення закріпилося найменше валової енергії - 170,7 ГДж/га. Внесення фосфорних та калійних добрив сприяло збільшенню валової енергії в кореневій масі до 198 ГДж/га, а за використання біопрепаратів цей показник зріс до 244,6 ГДж/га. Найвищі показники закріплення валової енергії в коренях зафіксовано у травостої із застосуванням інокуляції насіння конюшини лучної ризобофітом, найнижчі (201,9 ГДж/га) - за використання стимулятора росту екостим. Високим вмістом валової енергії в кореневій масі характеризувався травостій, де застосовували композиційно органо-мінеральне добриво добродій на фоні фосфорно-калійного удобрення та вапнування. Застосування вапнування у поєднанні iз стимулятором росту забезпечило невисокі показники - 203,8 ГДж/га валової енергії у кореневій масі.

Оцінку зміни валової енергї родючості грунту проводили на основі агрохімічного аналізу 3 врахуванням коефіцієнтів закріплення мінеральних добрив у грунті і енергозатрат на добрива. Сукупний запас енергії у грунті, в основному, залежить від вмісту гумусу i, в меншій мірі, від азоту, фосфору та калію [7].

За даними наших досліджень, енергоємність грунтової родючості довготривалого лучного агрофітоценозу за останні 5 років зросла 
на 1-20\%. Середньорічні темпи приросту запасів валової енергії на неудобреному травостої складали 22,5 ГДж/га, за внесення фосфорних та калійних добрив - 4,7 ГДж/га, та за внесення азотних добрив 0,8-7,1 ГДж/га. За внесення азотних добрив енергоємність родючості грунту збільшилася лише на 1-7 \%, причому за рівномірного внесення за останні п'ять років використання 41-річного злакового травостою приріст становив 35,65 ГДж/га, а за наростання доз до осені лише 4,05 ГДж/га. Відносно невисокі ці показники (23,7 ГДж/га) відмічені і за використання фосфорно-калійного удобрення. Застосування мінерального удобрення сприяло прискоренню процесу мінералізації органічної речовини дернини i реутилізації елементів живлення урожаєм трав. Найбільш високі темпи приросту енергетичних показників родючості грунту відмічені без використання удобрення, що було обумовлено високими темпами приросту запасів гумусу.

Енергоємність грунту новоствореного бобово-злакового лучного агрофітоценозу за п'ять років досліджень зросла на 12,48-105,55 ГДж/га. Без застосування удобрень енергоємність грунту зросла на 20\%. Найнижчі прирости енергоємності родючості грунту зафіксовано за внесення фосфорних та калійних добрив середньорічний приріст становив 2,6 ГДж/га, що за п’ять років використання бобово-злакового травостою забезпечило підвищення родючості грунту на $2 \%$.

При використанні у технології вирощування бобово-злакового травостою стимулятора росту за п'ять років приріст енергоємності грунту зріс на $8 \%$, а за додаткового застосування вапна - на $10 \%$. Застосування вапнякових добрив сприяло зниженню рівня кислотності грунту, що, в свою чергу, підвищило його енергонасиченість, адже при

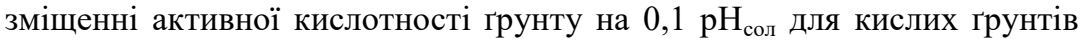
енергонасиченість зростає на 4,3 ГДж/га [382].

Отже, у грунтах бобово-злакових травостоїв за використання біопрепаратів накопичення валової енергії значно вище, ніж за використання мінерального удобрення на злакових довготривалих травостоях, що пов'язано із додатковим впливом біологічного фактору. Застосування стимулятора росту на фоні фосфорно-калійного удобрення та вапнування сприяло збільшенню частки бобових у травостої, що, в свою чергу, прискорило процеси мінералізації відмерлого коріння. 


\section{Література:}

1. Ярмолюк М.Т. та ін. Екологічне та природоохоронне значення кореневої маси лучних агрофітоценозів. Агроекологічний журнал. 2008. Спец. вип., червень. С. $272-275$.

2. Trükmann K. Quantifizierung der Stabilisierungseffekte von Pflanzenwurzeln als Möglichkeit zur Reduzierung der mechanischen Bodendeformationen in Grünland: doctoral thesis. 2011. ChristianAlbrechts-Universität $\mathrm{zu}$ Kiel. URL: http://eldiss.unikiel.de/macau/receive/dissertation_diss_00006942> (last accessed 16.06.2021).

3. Петрова С. Н., Парасин Н. В. Симбиотическая фиксация азота многолетними бобовыми травами. Кормопроизводство. 2000. № 3. C. 16-19.

4. Вацик В. О. Продуктивність бобових трав та бобово-злакових трав і сортосумішок при укісному використанні. Вісник аграрної науки. 2000. № 5. С. 67-68.

5. Крутило Д. В Бульбочкові бактерії - гетеротрофний та симбіотрофний способи життя. Сільськогосподарська мікробіологія. 2008. С.147-161.

6. Благовещенский Г. В. Инновационный потенциал бобового разнообразия травостоев. Кормопроизводство. 2013. № 12. С. 8-9.

7. Grman E., Bassett T., Brudvig L. Confronting contingency in restoration: management and site history determine outcomes of assembling prairies, but site characteristics and landscape context have little effect. Journal of Applied Ecology. 2013. Vol. 50. P. 1234-1243. 